\title{
RESEARCHERS FROM THE FACULTY OF NATURAL SCIENCES AND EDUCATION FOR INNOVATIVE EDUCATION: INNOVATIVE PEDAGOGY 1:1
}

\author{
Dejan Zemljak, Urška Martinc \\ University of Maribor, Slovenia
}

\author{
Andrej Flogie, Žiga Kobše \\ University of Maribor \& Institute Anton Martin Slomšek, Slovenia \\ Helena Fošnjar \\ University of Maribor, Slovenia \\ Maja Vičič Krabonja \\ Secondary School of Economics Maribor, Slovenia
}

\begin{abstract}
In 2017, the Faculty of Natural Sciences and Mathematics (FNM) of the University of Maribor entered the partnership of the project Innovative Learning Environments Supported by ICT - Innovative Pedagogy 1:1, led by the Institute Anton Martin Slomšek (ZAMS) and lasting from 2017 to 2022. Innovative Pedagogy 1:1 is a project focusing on the development of competences, which are "one of the fundamental prerequisites for lifelong learning and improved employability. One of the conditions for achieving this is the implementation of flexible forms of learning, which redefine the roles of all stakeholders involved: students, professionals and principals". The basic focus is on developing digital competencies of students, pedagogical and non-pedagogical staff, and school principals. This research describes the ways in which the Faculty of Natural Sciences and Mathematics, as an academic institution training pre-service teachers of Engineering and Technology, has supported project activities, how it participated in some of the project's key working bodies, and what its contribution is.
\end{abstract}

Keywords: academic collaboration, community, innovative pedagogy, project work

\section{Introduction}

The project Innovative Learning Environments Supported by ICT (short title: Innovative Pedagogy 1:1) is a $R \& D$ project, co-financed by the Ministry of Education, Science and Sport and the European Social Fund under Priority Axis 10: knowledge, skills and lifelong learning for better employability, and Investment Priorities 10.1: improving equal access to lifelong learning for all age groups in formal, non-formal and informal learning, updating knowledge, skills and competences on the site, and promoting flexible forms of learning, including through career counselling and validation of acquired competences. The project connects and upgrades the results of previous projects that have already begun to change learning environments in Slovenia, such as the reform of the "gymnasium" secondary school program, e-education, Innovative Pedagogy in the Light of 21st Century Competences 1:1, e-school bag, EU-folio, and ATS 2020.

The purpose of the project is to encourage a prudent and comprehensive use of tools, services, \# and portable devices, which in itself points to the challenge of overcoming 
the passive use of ICT in schools (cf. Aberšek et al., 2016). Targeted training, in connection with the exchange of good practices that support collaborative work through an efficient use of ICT; access to educational resources, monitoring of progress and evaluation of thought processes at higher taxonomic levels, presents teachers with various possibilities for creating learning opportunities and modern didactic approaches, such as problem-based learning, authentic assignments, project-based learning, and many others (cf. Mishra et al., 2006, pp. 1029). However, all stakeholders in education should be aware that the mere use of contemporary e-services and e-content does not in itself constitute a change. The use of such services alone does not mean that innovative teaching and learning methods have actually been introduced (cf. Anderson et al. 2016, pp. 56), however, it can strongly encourage and support their introduction if it is used in such a way as to enable the active role of students in appropriately organized flexible learning environments.

The project consortium consists of three stakeholder groups:

- Development institutions (National Education Institute, Faculty of Natural Sciences and Mathematics of the University of Maribor, Faculty of Education of the University of Maribor and Educational Research Institute),

- 20 development schools (DS) and

- 55 implementation schools (IS).

Both primary and secondary schools, including gymnasiums, are involved in the project, their role depending on their experience. Development schools are schools with experience in introducing innovative pedagogy and establishing learning communities (PLC). These schools were the first to become involved in the project activities, and later took on the leadership of the learning communities, each for their own cluster of implementation schools, as shown in Figure 1.

\section{Figure 1}

Connections between the Schools Involved in the Project

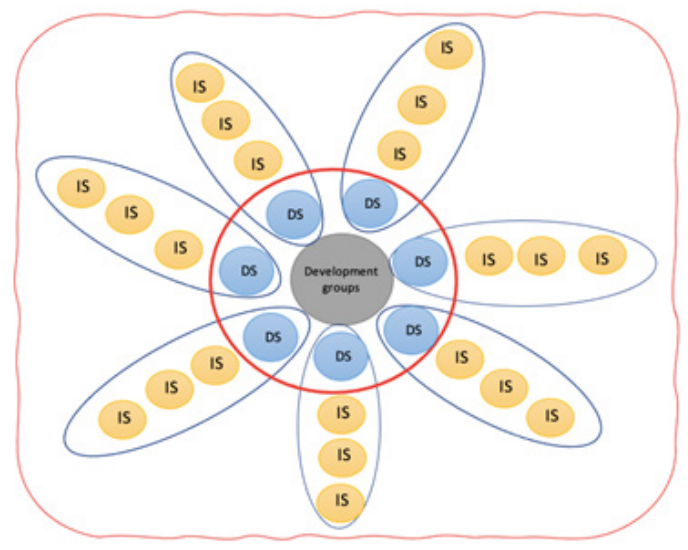

While one of the project objectives is school networking and establishing a Professional Learning Community (PLC), development institutions have taken on a responsible role in the development part of the project, the pillar of which are development groups in which development institution experts, principals and teachers of development schools participate equally. The work of ten development groups is intertwined in the following areas: upgrading pedagogical strategy, upgrading methodology, training teachers 
and principals, organization and dissemination of a professional e-community, planning, preparation and publication of good practice examples, implementation curricula (Aberšek et al., 2015, p. 190), implementation, technical aspects, testing and introduction of didactic e-services, evaluation, and promotion of the project.

The project Innovative Learning Environments Supported by ICT focuses on the development of competences, which are "one of the fundamental prerequisites for lifelong learning and improved employability. One of the conditions for achieving this is the implementation of flexible forms of learning, which redefine the roles of all stakeholders involved: students, professionals and principals"'.

Project activities are planned by 10 development groups operating within the project. Development groups consist of principals, teachers' representatives, and members of development institutions. Members of the Faculty of Natural Sciences and Mathematics are included in the following development groups:

- Upgrading pedagogical strategy,

- Upgrading methodology,

- $\quad$ Training of teachers and principals,

- Professional e-community

- Development group for technical aspects,

- Evaluation.

\section{Upgrading Pedagogical Strategy}

The development group for upgrading the pedagogical strategy is in charge of scientific research and presentation of project results. The group's main task is the organization of two international scientific conferences, which present key findings of the work carried out as part of the project, and provide an opportunity for networking of conference participants, especially teachers participating in the project.

One of the objectives of this group is the publication of their research findings in the form of a monograph, which is going to include sections on the upgrade of the pedagogical strategy, a methodology for the introduction of innovative pedagogy, as well as new scientific insights from this field of expertise. The monograph will bring together experts from various fields; therefore, its content will be diverse, but relevant to the field.

Editors of the monograph, which was originally created as part of a previous project and is going to be upgraded by the development group in this project, Contemporary Cognitive Education and Transdisciplinary Models of Learning (Sodobno kognitivno izobraževanje in transdisciplinarni modeli učenja), provide a concise description of the content:

"In this spirit, the fundamental problem of this book arises: how to define innovative teaching and place it on the map of 21st century education, while at the same time encouraging teaching and learning supported by ICT (e-services and e-content), and taking into account the necessary changes to the pedagogical paradigm (Flogie, 2014)? What we want to see happening in the field of education (or: what we should be striving towards) is the common thread of this book." (Aberšek et al., 2015, pp. 16).

The authors summarize the "theoretical starting points of contemporary pedagogy" (Aberšek et al., 2015, pp. 187) as follows:

- Placing central focus on the learning environment.

$1 \quad$ https://www.inovativna-sola.si 
- Developing a critical attitude towards the world and the individual.

- Recognizing and acknowledging the importance of emotions (motivation).

- Taking into account sensitive periods for language learning.

- Taking into account neuroscientific discoveries when reading.

- Incorporating several different ways of representation, evaluation, and commitment to learning.

- Building strong learning communities.

- Continuously adapting learning environments in order to incorporate new knowledge.

The participation of scientific staff from the Faculty of Natural Sciences and Mathematics in the project at this level represents both a foundation and an upgrade of project activities. As a scientific institution, the faculty prepares theoretical starting points as a basis for developing the project's vision and goals, and for planning project activities. During regular meetings, this group informs other members of the development group about new scientific findings, thus managing project activities in real time. At the same time, the organization of international conferences enables the dissemination of project results on a professional and scientific level. One such example of positive synergy was the PCE2020 conference, held in September 2020, which was aimed at all those involved in the co-creation and exploration of the education process in general, as well as all those interested in learning about the results of applied scientific research, good practices, and the most recent approaches in the field of teaching. Seventeen papers were presented on the scientific side, and 32 papers were presented by practicing teachers, who outlined their own professional experience from this field of expertise. ${ }^{2}$

\section{Figure 2}

The Role of the FNM as a Scientific Institution in the Development Group Upgrading of the Pedagogical Strategy

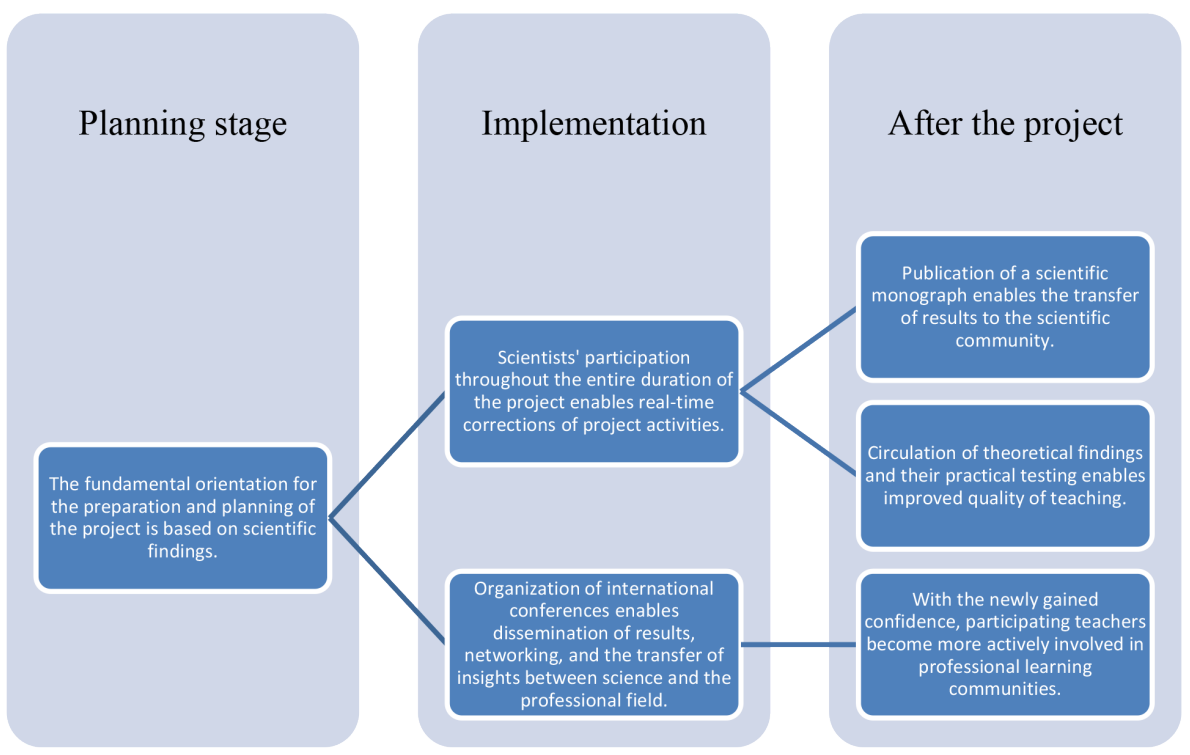




\section{Training of Teachers and Principals}

Numerous trainings have been prepared for teachers of Slovenian schools participating in the project, which have been carried out in various ways:

- $\quad$ internal trainings organized by individual schools, adapted to the needs of each team and mostly carried out by internal staff themselves;

- $\quad$ training of knowledge transmitters (trainings attended by interested teachers from all schools involved in the project, who then put their newly gained insights to the test in the classrooms, and disseminate them among colleagues in their schools);

- $\quad$ regular annual collective trainings, in which 4-10 teachers from each school participate. Such large meetings with more than 200 participants are an opportunity to host lectures by top scientists and experts in the field, but also an opportunity for networking among the teachers involved in the project, which helps to develop a wider learning community.

- distance trainings, performed once a month even in the period before March 2020, because they provide access to insights by top-level scientists and experts (fellow practicing teachers), all with minimal organizational costs.

The basic idea of trainings in the project is to promote the networking of schools in order to share experiences and help schools that are not skilled enough in introducing innovative learning environments. Trainings are regular, short and focused, and as a rule mandatory for teachers participating in the project. When planning such trainings, we have kept in mind that our goal is not only to present new knowledge, scientific insights, and good practice examples to the teachers, but also to encourage real changes in teaching, which is why lectures have been combined with workshops, during which teachers have the opportunity to work independently, because they can truly learn only by being actively involved. One of our basic guidelines was also connecting new, theoretical insights to practice.

As a scientific institution educating pre-service teachers from the fields of engineering and technology, mathematics, physics and biology, the Faculty of Natural Sciences and Mathematics has prepared several different trainings for the purposes of the project, as can be seen from Table 1: 


\section{Table 1}

Trainings for Teachers Organized and Implemented by the Faculty of Natural Sciences and Mathematics

\begin{tabular}{|c|c|}
\hline Title of the training & Objectives / expected achievements \\
\hline $\begin{array}{l}\text { Digital competences } \\
\text { and contemporary } \\
\text { teaching }\end{array}$ & $\begin{array}{l}\text { - Participants are aware and able to understand the need for new, more active } \\
\text { approaches to learning and teaching, and understand their own role in this. } \\
\text { Participants learn about didactic approaches in using modern ICT (tablets, } \\
\text { smart phones), and gain relevant experience in this area. } \\
\text { - Through independent research, creation, design, planning and evaluation } \\
\text { as part of the workshops, participants learn about and develop their } \\
\text { own creative skills, abilities of constructive and critical thinking and } \\
\text { collaborative learning. } \\
\text { Through experiential learning, participants acquire competences, which } \\
\text { are necessary to employ contemporary teaching methods. }\end{array}$ \\
\hline
\end{tabular}

An innovative
teaching method for
improving classroom
atmosphere and
motivation

motivation

Contemporary

learning environments and AI
Through specific, concrete examples, participants learn about various innovative approaches to problem solving, which helps to raise a positive atmosphere in the classroom and increase students' interest in the subject.

At the same time, students develop their own way of learning by searching for ideas, acquire knowledge in order to achieve goals, and develop cooperation.

- Participants are aware and able to understand the need for new, more active approaches to learning and teaching, and understand their own role in this.

- Participants become familiar with different approaches to using contemporary technologies and gain relevant experience in this field.

- As part of the workshops, participants learn about latest technology development trends, and develop creative ways of using such technologies.

- Participants acquire competences, which are necessary to employ contemporary teaching methods.

- Participants are aware and able to understand the need for new, more active approaches to learning and teaching, and understand their own role in this.

Contemporary teaching as a teaching method function
- Participants learn about didactic approaches in using contemporary technologies, and gain relevant experience in this area,

- As part of the workshops, participants learn about and develop their own creative skills, abilities of constructive and critical thinking and collaborative learning; on the basis of their own experience, they acquire competences which are necessary to employ contemporary teaching methods.

- Participants improve their scientific writing skills.

- Participants understand the importance of taking into account the recipient of the written communication.

- $\quad$ Participants acquire the ability to communicate in writing with non-expert (e.g., parents) and professional audiences.

- $\quad$ Through independent creation, design, planning and evaluation as part of

Scientific writing the workshops, participants learn about and develop their own creative writing and speaking skills, abilities of constructive and critical thinking and the ability to express themselves clearly, while taking into account the recipient of the communication.

- Through experiential learning, participants acquire competences, which are necessary to employ contemporary teaching methods for written communication. 
Monitoring of project activities shows that the trainings have significantly contributed to the progress of teachers involved in the project.

One such example, which deserves special attention, is the training dedicated to writing scientific and scholarly papers. Due to great interest, this training was repeated several times, and even upgraded for the most interested teachers. Writing papers has already become quite popular among Slovenian teachers, especially in light of the existing teacher promotion system. Namely, in accordance with the Rules on the Promotion of Employees in Education to Titles ${ }^{3}$, this is one of the possibilities for earning points for promotion. The faculty, as an institution educating pre-service teachers, is aware that writing scholarly papers should not only serve as a means of collecting points and sharing good practice examples, but also as an opportunity to develop reflective teaching that goes beyond routine conduction of classes. A lack of reflective teaching in Slovenia was already pointed out by Marija Javornik Krečič (2008: 16) in 2008, who saw an opportunity to respond to this challenge in the Bologna Process higher education reform. Since then, several projects (e.g., Linpilcare) have been systematically involved in this field. Project coordinators have tried to make use of the teachers' high level of motivation to write papers, thus encouraging them to analyse their own teaching. Teachers who prepared their contributions as part of this training were also given the opportunity to present their work at the International Scientific Conference on the Philosophy of Mind and Cognitive Modelling in Education (PCE2020). One of the results of this training are the papers published in the conference proceedings.

\section{Professional E-community}

Exchanging and disseminating results and maintaining activities even after a project ends is one of the core challenges of any project. For this purpose, a great deal of energy was invested into building a Professional Learning Community of teachers as part of the project. Because participating schools are from all over the country, this PLC was named the "Professional e-community". It operates on several levels, which create strong synergy effects through their interconnection:

- The level of teachers involved in the project at each school

- The level of all teachers in each school

- Connections and participation of teachers from different schools (school networks)

- $\quad$ Participation of all teachers involved in the project (75 schools)

- Public announcements and open-access online trainings for all teachers in the country.

In achieving this goal, the development group has worked closely with other development groups, especially the training group.

The task of the member of the Faculty of Natural Sciences and Mathematics who participated in this group was primarily to transfer new theoretical knowledge from the field of PLC and to promote the inclusion of academic staff and students in the emerging PLC. The publication of news from the online classroom and the project's Facebook page on the faculty's website, and vice versa, has been very helpful in achieving this effect.

3 http://www.pisrs.si/Pis.web/pregledPredpisa?id=PRAV4272 


\section{Development Group for Technical Aspects}

The development group for technical aspects played a crucial role especially at the beginning of the project, during the so-called preparatory year, which was mainly dedicated to teacher training, planning school activities and equipping students and teachers with mobile devices. Since no funds were allocated to providing equipment in this project, it was important for the development group to prepare recommendations in a timely manner. These recommendations included:

- Various proposals for the purchase of mobile devices (BYOD, personalized tablets that students carry home, daily loan of tablets at schools).

- $\quad$ Minimum system requirements for mobile devices needed to conduct ICTsupported classes.

- Different models of device maintenance and mass management, AAI account management and web connections.

It should be noted that schools purchased devices that ran on different operating systems, which meant that recommendations and training for computer technicians/ organizers of informative activities needed to be tailored to the needs of different users.

A major field of action for this group was online safety. The focus was on individual stakeholder groups in the project: computer technicians/organizers of informative activities, teachers, parents, and students.

Lecturers from the Faculty of Natural Sciences and Mathematics were involved in the process of preparing these documents and conducting the trainings as a priceless source of expertise. They had the opportunity to gain feedback from practical work by gathering experiences of practicing teachers and their responses to theoretical knowledge, which they were then able to implement in their own work with students, who will soon be entering schools, where they themselves will be confronted with the above challenges.

\section{Evaluation}

The basic task of the evaluation group is to evaluate the achievements of the project. This ensures both formative and final verification of achieving the goals, which were set out at the beginning of the project. The task of evaluation was entrusted to the Educational Research Institute. At the end of the project, the evaluation team envisages visible progress in the development of digital competence in students and teachers. It is also expected that elements of formative monitoring, as well as elements of encouraging the development of critical thinking, cooperation and problem solving in teachers' pedagogical practice, will be evident in the end stage of the project. For the purposes of evaluation, various questionnaires were designed, and members of the Faculty of Natural Sciences and Mathematics played a vital role in preparing them. As an institution that educates pre-service teachers of science, information science and technology, the Faculty of Natural Sciences and Mathematics participated mainly in compiling questions on the development of digital competences, critical thinking and problem solving. In addition to a self-assessment questionnaire, tasks were prepared to test the actual digital competence of all teachers and students involved in the project, according to the Digital Competence Framework (Carretero et al., 2017). 


\section{Conclusion - the Role of the Faculty in the Project}

The role of the Faculty of Natural Sciences and Mathematics as a scientific research institution in the project is primarily to provide professional (specialist) and scientific support to project participants. Researchers and scientists from the Faculty of Natural Sciences and Mathematics are directly involved in all stages and activities of the project. The findings derived from their research were included in the planning of goals and activities of individual development groups, as well as in the preparation of various recommendations for teachers of Slovenian schools.

The participation of experts, scientists and teachers in the project thus adds value to the research findings, which are ready to be used in practice. In this way, faculty researchers have helped the experts, guiding them in the preparation of work tasks for individual groups, with which they achieved the set goals. At the same time, the teachers tested the recommendations and suggestions in practice during their classes. Their findings were presented to faculty researchers and other experts. Thus, a comprehensive system has been established, which offers opportunities both for the design of various strategies and their evaluation. Continuous support between professionals from the field of science and teachers ensures continuous progress and leads to a successful attainment of project objectives. At the same time, cooperation with practicing teachers is an opportunity for the faculty to test theoretical knowledge in practice and receive quality feedback, which helps to raise the quality of the study process for pre-service teachers.

The participation of the Faculty of Natural Sciences and Mathematics as a scientific institution is a valuable contribution to the success of the project, which leads to further cooperation and the establishment of PLCs that can help improve the quality of education in the field of introducing innovative teaching methods and approaches.

\section{References}

Aberšek, B., Flogie, A., \& Šverc, M. (2015). Sodobno kognitivno izobraževanje in transdisciplinarni modeli učenja. [Modern cognitive education and transdisciplinary learning models]. Fakulteta za naravoslovje in matematiko Univerze v Mariboru.

Carretero, S., Vuorikari, R., \& Punie, Y. (2017). DigComp 2.1: The Digital Competence Framework for Citizens: with eight proficiency levels and examples of use. Publications Office of the European Union. https://publications.jrc.ec.europa.eu/repository/handle/JRC106281

Inovativna šola [Innovative school]. https://www.inovativna-sola.si

Javornik Krečič, M. (2008). Reflektivno poučevanje - značilnosti, modeli in pristopi [Reflective teaching - characteristics, models and approaches]. Pedagoška obzorja = Didactica Slovenica: časopis za didaktiko in metodiko, 23(1), 3-18.

4th International Scientific Conference on Philosophy of Mind and Cognitive Modelling in Education (2020). PCE2020. http://pce.fnm.um.si

Pravilnik o napredovanju zaposlenih v vzgoji in izobraževanju v nazive [Rules on the promotion of employees in education to titles]. (2021). Uradni list RS, št. 54/02, 123/08, 44/09, 18/10 in 113/20. http://www.pisrs.si/Pis.web/pregledPredpisa?id=PRAV4272

Received 25 April 2021; Accepted 18 June 2021 
Cite as: Zemljak, D., Martinc, U., Flogie, A., Kobše, Ž., Fošnjar, H., \& Vičič Krabonja, M. (2021). Researchers from the Faculty of Natural Sciences and Education for innovative education: Innovative pedagogy 1:1. Gamtamokslinis ugdymas / Natural Science Education, 18(1), 45-54. https://doi.org/10.48127/gu-nse/21.18.45

\section{$\square \quad 0$ \\ Dejan Zemljak}

MSc, Research Assistant, Department of Technical Education, Faculty of Natural sciences and Mathematics, University of Maribor, Maribor, Slovenia.

E-mail: dejan.zemljak1@um.si

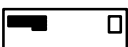

\section{Urška Martinc}

Assistant, Department of Technical Education, Faculty of Natural sciences and Mathematics, University of Maribor, Maribor, Slovenia.

E-mail: urska.martinc1@um.si

\section{\begin{tabular}{ll}
\hline Andrej Flogie \\
\end{tabular}}

$\mathrm{PhD}$, Assistant Professor, Department of Technical Education, Faculty of Natural sciences and Mathematics, University of Maribor and Institute Anton Martin Slomšek, Maribor, Slovenia.

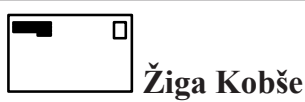

Assistant, Department of Sociology, Faculty of Arts, University of Maribor and Institute Anton Martin Slomšek, Slovenia.

E-mail: ziga.kobse@um.si

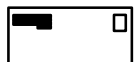

\section{Helena Fošnjar}

Assistant, Department of Technical Education, Faculty of Natural sciences and Mathematics, University of Maribor, Slovenia.

E-mail: helena.fosnjar@um.si

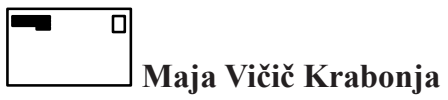

Teacher, Secondary School of Economics Maribor, Maribor, Slovenia.

E-mail: maja.vicic@ses.mb.si 